\title{
Brassicaceae-Derived Anticancer Agents: Towards a Green Approach to Beat Cancer
}

\author{
Luigi Mandrich ${ }^{1}\left(\mathbb{D}\right.$ and Emilia Caputo ${ }^{2, *}$ \\ 1 Research Institute on Terrestrial Ecosystems-IRET-CNR, Via Pietro Castellino, 111, I-80131 Naples, Italy; \\ luigi.mandrich@cnr.it \\ 2 Institute of Genetics and Biophysics (I.G.B.) “A. Buzzati-Traverso", CNR, Via Pietro Castellino, 111, \\ I-80131 Naples, Italy \\ * Correspondence: emilia.caputo@igb.cnr.it
}

Received: 16 November 2019; Accepted: 11 March 2020; Published: 24 March 2020

\begin{abstract}
Cancer is the main cause of mortality and morbidity worldwide. Although a large variety of therapeutic approaches have been developed and translated into clinical protocols, the toxic side effects of cancer treatments negatively impact patients, allowing cancer to grow. Brassica metabolites are emerging as new weapons for anti-cancer therapeutics. The beneficial role of the consumption of brassica vegetables, the most-used vegetables in the Mediterranean diet, particularly broccoli, in the prevention of chronic diseases, including cardiovascular diseases, diabetes, and obesity, has been well-documented. In this review, we discuss the anti-tumor effects of the bioactive compounds from Brassica vegetables with regard to the compounds and types of cancer against which they show activity, providing current knowledge on the anti-cancer effects of Brassica metabolites against major types of tumors. In addition, we discuss the impacts of industrial and domestic processing on the compounds' functional properties before their consumption as well as the main strategies used to increase the content of health-promoting metabolites in Brassica plants through biofortification. Finally, the impacts of microbiota on the compounds' bioactivity are considered. This information will be helpful for the further development of efficacious anti-cancer drugs.
\end{abstract}

Keywords: Brassicaceae; plant metabolites; cancer drugs; microbiota; dietary agents

\section{Introduction}

A large variety of tumors affect the human population. Cancer is characterized by a deregulation of key cellular functions, such as growth signaling, anti-apoptotic signaling, gene stability, immune response, and stromal microenvironment regulation [1]. Although prevention, control strategies, and different treatments are available, the number of cancer patients increases each year, as does the mortality rate for this disease [2].

Numerous clinical trials have been developed to investigate potential cancer cures. However, their toxic side effects have had negative impacts on the patients. Radiotherapy and chemotherapy show severe side effects due to their toxicity on healthy cells. Target-based therapy and immunotherapy, although highly specific in cancer targeting, can be applied to a limited target patient range and are very expensive. Furthermore, several kinds of cancer tend to relapse and acquire resistance after treatment. Currently, combined therapies are substituting monotherapy treatments to overcome their limitations [3]. Moreover, significant effort is being made to search for more effective drugs with reduced side effects from new sources. 
For millennia, plants have been used in medical cures. Plant metabolites show a wide range of biological functions, such as anti-cancer, anti-analgesic, antimicrobial, and anti-inflammation activities. More than $60 \%$ of drugs with anti-cancer activity are derived from plants [4]. Therefore, plant metabolites represent a good source for the development of efficacious therapeutic agents with reduced side effects.

Several studies have reported the chemopreventive and anti-cancer properties of dietary agents. It has been observed that vegetable consumption is associated with a lower risk of developing cancer. Our main interest is vegetables belonging to the Brassicaceae family, such as broccoli and cauliflower, as these vegetables are a source of glucosinolates (GLs), from which other biologically active products are derived $[5,6]$. Unfortunately, the approach of these studies seems to be heterogeneous and not conclusive [6].

In this review, we discuss the potential properties of GLs derived from Brassicaceae as chemopreventive and anti-cancer agents, with respect to their absorption and metabolism in the human body.

\section{Brassicaceae}

Brassicaceae (Cruciferae) is a large plant family including a wide range of vegetables, condiments, forage, and oil seed crops such as broccoli, cauliflower, cabbage, kohl rabi (all cultivars of Brassica oleracea), radish (Raphanus sativus), mustard (Sinapis alba), and rapeseed (B. napus), as well as ornamentals (e.g., Arabis, Aubrieta, Erysimum, Iberis, Lunaria, Matthiola, and others), comprising several model plants (e.g., Arabidopsis thaliana, A. suecica, Arabis alpina, Cardamine hirsuta) [7].

Brassicaceae, also known as the "mustard" family, includes approximately 338 genera and 3709 species and is distributed worldwide in all continents except Antarctica. However, the species diversity is not equally distributed, and the most important diversification centers are found in the Irano-Turanian and Mediterranean regions [8-10]. Their distribution pattern and several recent studies suggest that this plant family originated and diversified in the eastern Mediterranean (Asia Minor or present-day Turkey) and adjacent regions [11,12].

The crucifers are phylogenetically sisters to the Cleomaceae family, and both families belong to the Brassicales order [13,14]. A robust and reliable family tree has been recently developed [15]. It is based on more than 100 orthologous nuclear markers retrieved from sequenced transcriptomes of 55 species belonging to the five major clades within the crown group (Figure 1). 


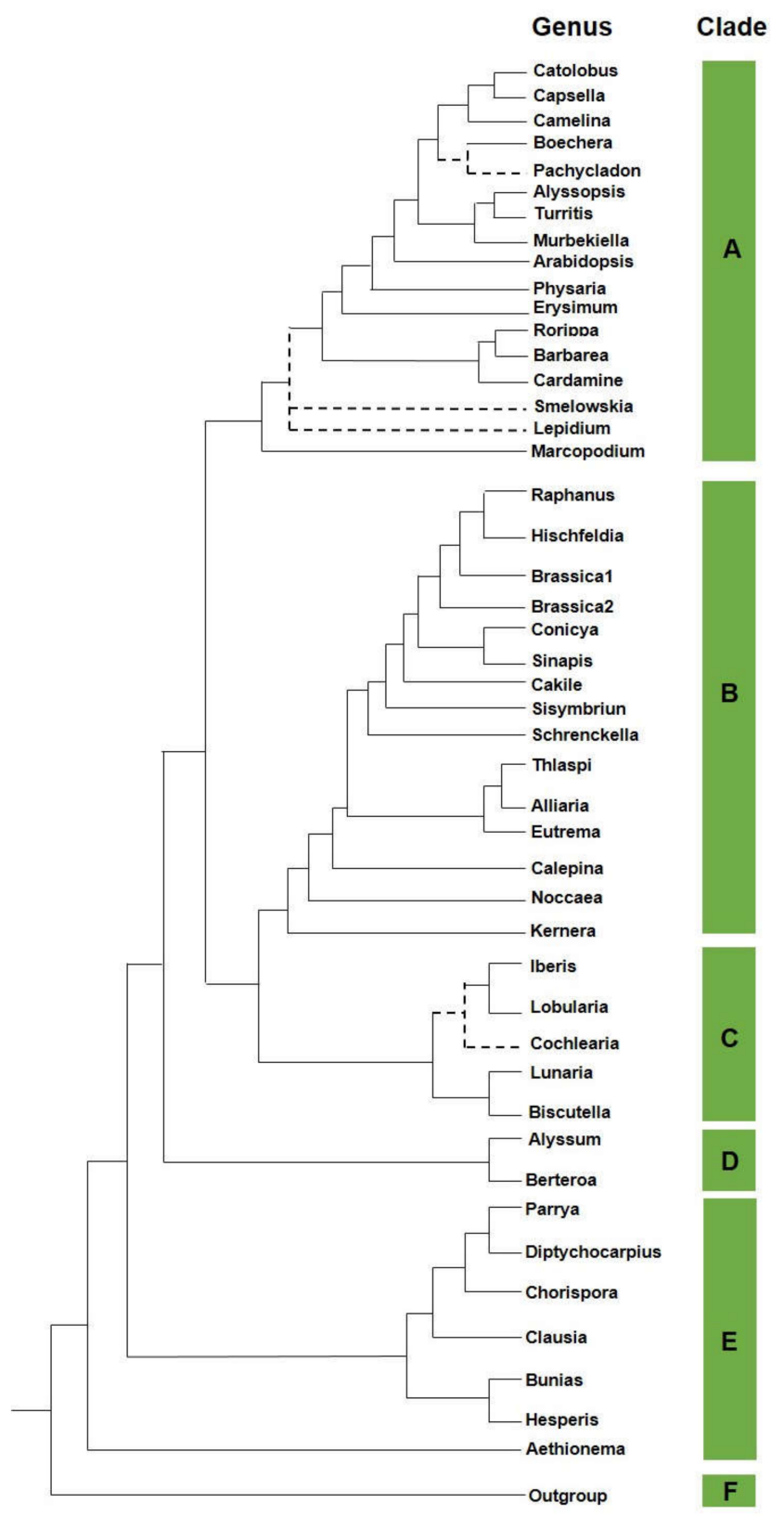

Figure 1. Phylogeny in Brassicaceae. A schematic phylogenetic relationship in the Brassicaceae family.

\section{Brassicaceae Phytochemicals}

As with many other vegetables, crucifers are high in minerals, nutrients, and phytochemicals (e.g., selenium, folate, and fiber). Particularly, these vegetables are rich in sulfur-containing compounds, called glucosinolates (GLs), which are responsible for their pungent and spicy taste [16]. GLs are especially abundant among families of the order Capparales: Tovariaceae, Resedaceae, Capparaceae, Moringaceae, and Brassicaceae. Families outside the order exhibit occasional occurrences and include Caricaceae, Euphorbiaceae, Gyrotemonaceae, Limnathaceae, Salvadoraceae, and Tropaeolaceae [17].

It has been demonstrated that the chemopreventive potential of cruciferous vegetables is likely due to glucosinolates and their secondary metabolites (e.g., isothiocyanates (ITCs)) [18]. So far, more than 130 different glucosinolates have been identified from various plants, and the profiles of these compounds vary depending on cultivars and growing conditions. Depending on the molecular 
structure, they can be classified as aliphatic, aromatic, v-methylthioalkyl, or heterocyclic glucosinolates (Figure 2) $[16,19,20]$.

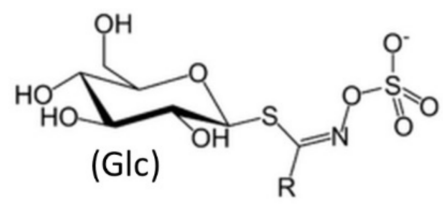

Figure 2. Glucosinolate structure. In the schematic structure of glucosinolate, $\mathrm{R}$ is an aliphatic, aromatic, v-methylthioalkyl, or heterocyclic residue.

GLs can be hydrolyzed by myrosinase (thioglucoside glucohydrolase, EC 3.2.1.147, formerly EC 3.2.3.1) to produce D-glucose and various other degradation products. Both the enzyme and substrates physically coexist in plants but are separated from each other. In Arabidopsis thaliana, GLs have been detected between the phloem and the endoderm, whereas myrosinase is found in the neighboring phloem parenchyma [21]. Further, it has been demonstrated that myrosinase is localized in specialized GLS-free idioblast cells, termed myrosin cells, and its activity is highest in the seed and seedling stages [22-24].

Initially, myrosinase-modified GLs release thiohydroximate-O-sulfate, an unstable aglucone (Figure 3). In the presence of the so-called epithiospecifier proteins (ESPs), aglucone degradation leads to the release of epithionitriles (EPTs) from alkenyl GLs [25-27] and nitriles from non-alkenyl GLs [28-30]. In the absence of ESPs, the aglucones spontaneously rearrange to form isothiocyanates (ITCs) and small amounts of nitriles. Nitrile specifier proteins (NSPs), which favor nitriles, as well as epithiospecifier modifiers (ESMs), which, in turn, favor isothiocyanate formation, have also been identified in Arabidopsis thaliana [28,31].

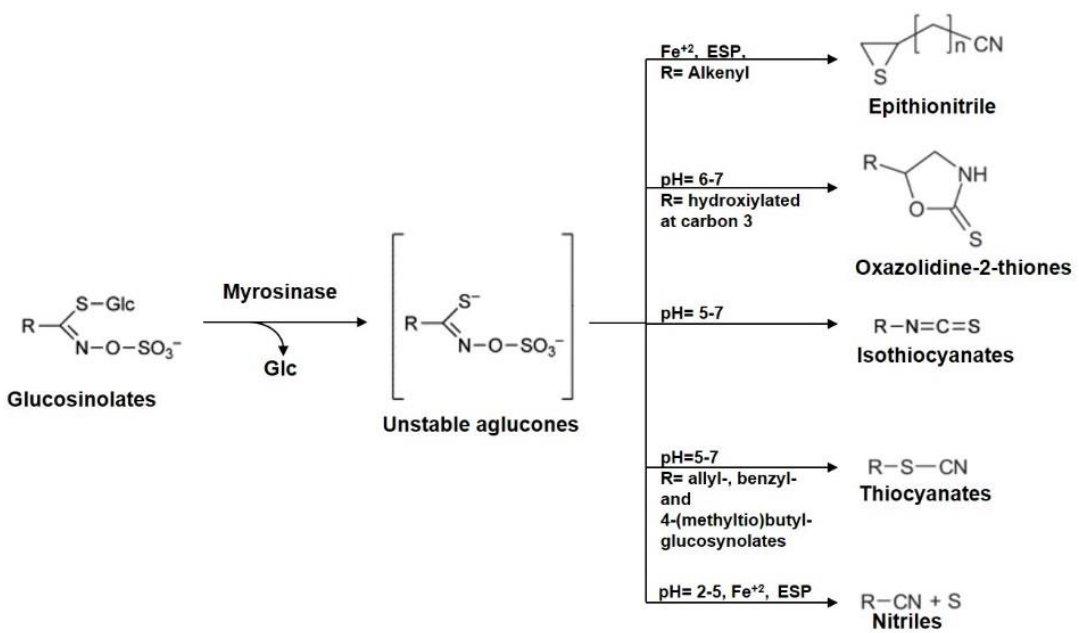

Figure 3. Simplified representation of glucosinolates (GLs) and their hydrolysis products. Myrosinase acts on GLs to form an unstable aglycone intermediate. It can rearrange spontaneously generating an isothiocyanate at neutral $\mathrm{pH}$. Under certain conditions, such as in the presence of nitrile specifier proteins (NSPs), ferrous ions, or at $\mathrm{pH}<5$, GL hydrolysis is responsible for the formation of the corresponding nitriles. Instead, in the presence of epithiospecifier proteins (ESPs), GL hydrolysis gives epithionitriles from alkenyl GLs through a ferrous ion-dependent mechanism.

Various studies suggest that GLs may play an important role in herbivore and microbial defense by their potent odor and taste [16]. High levels of these compounds ("mustard oil bomb") are quickly released upon tissue damage, constituting a very effective defense against some generalist herbivores [32]. Further, GL degradation products are known for their fungicidal, bactericidal, 
nematocidal, and allelopathic properties $[33,34]$. Recently, GLs and their degradation products have attracted intense research interest because of their cancer chemoprotective properties.

In plants, the GL profiles and contents are affected by various parameters, including: temperature, irradiation, nutrition, and water supply [35]; their management (organic vs. conventional) [36]; wounding and biotic factors, such as herbivores [37,38]; and by intrinsic plant-determined factors, such as (onto)genetic influences, which can induce an enormous variation in GL levels, even within the plant [39]. Furthermore, according to the stage of plant development, different GL profiles have been found. High concentrations of aliphatic or aromatic GLs have usually been found in seeds [39-41], while after germination, their content progressively decreases and the total GL content increases due to higher indole GL levels [39,40,42].

\section{ITC Anti-Cancer Activity in Different Tumors}

In vitro and in vivo studies have shown that ITCs are able to activate phase II detoxification enzymes (such as quinone reductase and glutathione S-transferase) as well as to disrupt tubulin polymerization, inducing cell cycle arrest and the activation of apoptosis in cancer cells [43]. Additionally, since dietary ITCs are well absorbed and have good bioavailability, these compounds are promising candidates for anti-cancer therapies [44-46].

Particularly, the bioactivity and fate of the downstream metabolites sulforaphane (SFN) and erucin (ECN) from alkyl isothiocyanates, as well as indole-3-carbinol from indolyl glucosinolates, have been heavily investigated in humans to explore their roles in carcinogenesis and cancer progression modulation (Table 1).

Table 1. Active metabolites from glucosinolates and their roles in more frequent cancer types (AKT, protein kinase B; PTEN, phosphatase and tensin homolog).

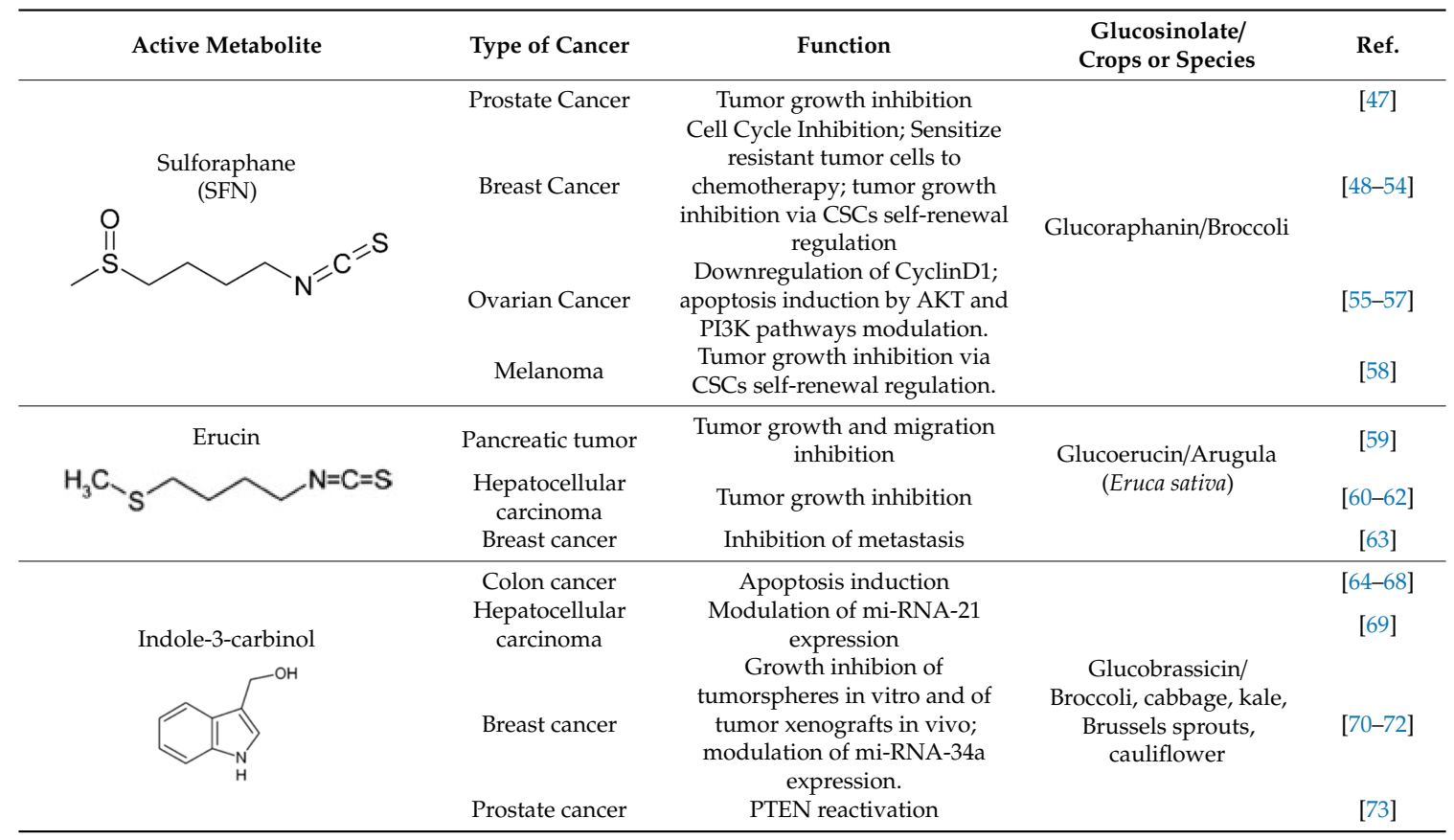

\subsection{Alkyl Isothiocyanates and Cancer}

\subsubsection{Sulforaphane}

Several studies have shown that SFN induces apoptosis and inhibits the progression and metastasis of many cancers [73-75].

Recently, it was found that the consumption of glucoraphanin-rich broccoli soup affects gene expression in the prostates of men on active surveillance, consistent with a reduction in the risk of 
cancer progression [47]. Broccoli sprouts are considered a functional food as they are naturally enriched in glucoraphanin (GR), which is the biological precursor of sulforaphane (SFN), a compound mainly found in broccoli sprouts, Chinese kale, cabbage, and watercress. Due to its health-promoting value, broccoli sprout juice is becoming very popular.

It was previously reported that dietary consumption of SFN and broccoli was correlated with a reduction in tumor size and growth in a breast cancer rodent model [48]. It has been demonstrated that this effect may be associated with the role of SFN in repressing the cyclin-dependent kinase 4D-type cyclin (CDK4-CCND) complex via the downregulation of SERTAD1 gene expression, leading to an increase in the breast cancer population in the G1 phase [49].

Moreover, the anti-cancer effects of SFN and other bioactive phytochemicals from medicinal plants have been investigated in combination with conventional therapies for breast cancer treatment [50]. Interestingly, it has been observed that docetaxel (at a dose of $10 \mathrm{mg} / \mathrm{kg}$ once every 7 days) decreased tumor growth of established tumors by $83.2 \%$, whereas SFN (at a dose of $50 \mathrm{mg} / \mathrm{kg}$ daily) inhibited primary tumor growth by $37.4 \%$ in a SUM149 breast tumor xenograft mouse model. The combination of SFN and docetaxel enhanced the reduction in the primary tumor volume $(92.5 \%$ reduction compared with control) and synergistically inhibited the cancer stem cell (CSC) population compared with docetaxel alone [51].

Furthermore, preliminary data show that SFN may prevent or treat breast cancer by inducing estrogen-induced metabolic changes [52]. It has been demonstrated that estrogen can enhance purine metabolism to promote DNA biogenesis, while estradiol treatment was shown to induce an increase in amino acids levels, such as L-proline and L-arginine in breast cancer cells (MCF-7). Both purine metabolites and amino acids are critical nutrients for cells, providing them with the necessary energy and cofactors to stimulate their cell survival and proliferation and thus tumor progression. In this context, it has been observed that SFN reduces the levels of related purine metabolites and amino acids in MCF-7 cancer cells, providing a novel insight into the potential mechanism by which SFN may act as a cancer chemopreventive agent.

Additionally, it was demonstrated that sulforaphane is able to reduce the proliferation capacity of human (SKOV3) and mouse (C3 and T3) ovarian cancer cell lines by downregulating cyclin D1 and cyclin-dependent kinases 4 and 6 (CDK4 and CDK6) [55].

Interestingly, sulforaphane has been shown to sensitize cancer cells resistant to chemotherapy. SFN overcame adriamycin- and cisplatin-resistance in ovarian cancer, suggesting that it may help to reduce chemotherapeutic compound doses as well as their side effects [56,57].

The effects of SFN have also been evaluated in melanoma. It has been demonstrated that SFN impairs the viability of melanoma cell lines (A375 and 501MEL cells) in a dose- and time-dependent manner, while it does not affect non-cancerous epidermal melanocytes (HEMa). Studies have shown that SFN increases the percentage of apoptotic melanoma cells by cleaving poly (ADP-ribose) polymerase (PARP), activating p-p53, caspase-3, caspase-8, and caspase-9, and decreasing Bcl2 expression, thus confirming its pro-apoptotic role. SFN is a very attractive multipotent anti-cancer agent, and its use could open new avenues for preventing tumor growth and treating human malignancies [58]. Sulforaphanes as well as other phytocompounds (e.g., curcumin, epigallocatechin gallate (EGCG), resveratrol, lycopene, SR-T100, several flavonoids, wogonin, Wisteria floribunda agglutinin (WFA), ginsenosides, and genistein derivatives) have been demonstrated to reduce CSC-related marker levels and inhibit CSC-related signaling pathways in ovarian cancer, suggesting their potential use to overcome its chemoresistance and relapse, mainly due to the CSC fraction [76].

Interestingly, SFN reverses gefitinib tolerance in human lung cancer cells via the modulation of Sonic Hedgehog (Hh) signaling [77] and regulates the self-renewal of pancreatic CSCs through the Sonic Hh pathway both in vivo and in vitro [78,79]. Additionally, SFN demonstrated a suppressive effect on gastric CSCs via the Sonic Hh pathway [79]. 


\subsubsection{Erucin}

Erucin (ERU) is an isothiocyanate derived from the glucosinolate glucoerucin, which is typically found in high amounts in wild rocket (from Eruca sativa Mill.).

ERU is also derived from SFN biotransformation by sulfur atom reduction in the human body [80], and has been described as a slow $\mathrm{H}_{2} \mathrm{~S}$-releasing compound $[81,82]$ like other natural ITCs such allyl isothiocyanate, 4-hydroxybenzyl isothiocyanate, benzyl isothiocyanate, and SFN (previously described). $\mathrm{H}_{2} \mathrm{~S}$ is a well-known endogenous gasotransmitter, which plays a critical role in the cardiovascular and respiratory systems as well as in cell growth regulation.

Anti-cancer and chemopreventive activities are some of the proposed biological properties described for isothiocyanates. Interestingly, it is their particular behavior known as "hormesis" that has also been used to describe the action of the endogenous gasotransmitter hydrogen sulfide $[83,84]$. ITCs and low $\mathrm{H}_{2} \mathrm{~S}$ concentrations are able to promote cell proliferation, whereas high concentrations inhibit cell proliferation, migration, and angiogenesis in a variety of cancers [84].

It has been described that endogenous $\mathrm{H}_{2} \mathrm{~S}$, as well as exposure to low levels of exogenous $\mathrm{H}_{2} \mathrm{~S}$ donors for a short time, lead to anti-apoptotic effects in tumor cells, enhancing cancer growth [84]. On the contrary, long-term treatment with a relatively high concentration of $\mathrm{H}_{2} \mathrm{~S}$ donors inhibits tumor cell proliferation in different types of cancers, thus suggesting that slow-releasing $\mathrm{H}_{2} \mathrm{~S}$ donors may represent a promising anti-cancer therapeutic strategy $[83,84]$.

ERU is able to increase the release of $\mathrm{H}_{2} \mathrm{~S}$ inside AsPC- 1 cells, one of the most aggressive pancreatic adenocarcinoma cell lines, in a concentration-dependent manner, exhibiting a hermetic behavior similar to other natural $\mathrm{H}_{2} \mathrm{~S}$ donors showing anti-cancer effects [59], such as GYY4137 [60,61] and acetyl deacylase disulfide [62].

Interestingly, ERU, combined with lapatinib, is able to strongly decrease the metastatic potential of breast tumor cells, even the ones with a drug-resistant phenotype [63].

\subsubsection{Indole-3-Carbinol in Cancer}

Indole-3-carbinol (I3C) is a natural compound derived from the breakdown of the glucosinolate glucobrassicin, which is found in broccoli, cauliflower, cabbage, collard greens, Brussels sprouts, and kale [85].

I3C has shown antiproliferative effects in several colon cancer cell lines (HT29, WS480, Colo320, Caco-2, HCT-116) [64-68] and hepatocellular carcinoma cells [69]. Interestingly, this molecule is able to induce cell cycle arrest by upregulating mi-RNA-34a expression in MCF-7 human breast cancer cells as well as cell death via the apoptosis of ER $\alpha$-positive breast cancer cells [70,71].

However, most of this evidence refers to in vitro experiments. The process is more complex in vivo. The main critical point is the measurement of these compounds in the organism, for example, isothiocyanates are rapidly metabolized in the gut and liver and are eliminated in urine; furthermore, their half-lives and effectiveness depend on a number of factors, such as how they are absorbed through food, the frequency of absorption, the metabolism of these compounds, as well as genetic factors due to polymorphisms, which can modify the absorption and metabolism of phytochemicals.

\section{Anti-Cancer Properties of GL Metabolites and Their Bioavailability}

As mentioned in the previous section, evidence has shown the potential anti-tumor properties of GL metabolites by using in vitro cell assay, where purified GL metabolites are administrated to cancer cell lines to evaluate the effect of their activity on their survival. However, these assays did not take into account various parameters that affect the bioavailability of these compounds when they are administrated into the diet of humans. For example, the brassica variety, the amount that should be introduced into the diet of cancer patients to be efficacious against tumor progression, and the storage, handling, processing, and cooking of brassica crops to get the maximal bioavailability of their active compounds are some important issues addressed in several investigations. 
It was demonstrated that the metabolic content of different GLs depends on the storage, preparation, and cooking processes used. These processes cause the rupture of cellular membranes in the plant leading to contact between GLs and the myrosinase enzyme and then to GL hydrolysis [17,25]. A 5-10-fold change in the concentration of glucosinolates from Brassica vegetables during the post-harvest stages was reported [36,86]. Moreover, previous research demonstrated that partial or total inactivation of myrosinase, breakdown of glucosinolates at high temperatures, loss of enzymatic cofactors, leaching of glucosinolates and their metabolites into the cooking medium or volatilization, and/or thermal degradation of the metabolites can occur during cooking, as simplified in Table 2 [86].

Table 2. Factors influencing GL content. Storage conditions and cooking are the main factors involved in the loss of GLs. Here are the reported cases of broccoli; however, different species of Brassicaceae are affected in different modes with respect to broccoli *.

\begin{tabular}{|c|c|c|c|c|c|}
\hline \multirow[b]{3}{*}{$\begin{array}{c}G L^{* *} \\
\text { decrease }\end{array}$} & \multicolumn{5}{|c|}{ Storage Conditions } \\
\hline & $\begin{array}{c}\text { closed } \\
\text { environment room } \\
\text { temperature } \\
\text { (5 days) }\end{array}$ & \multicolumn{2}{|c|}{$\begin{array}{c}\text { open environment room } \\
\text { temperature } \\
\text { ( } 3 \text { days })\end{array}$} & $\begin{array}{c}\text { polymeric bags room } \\
\text { temperature } \\
\text { (7 days) }\end{array}$ & $\begin{array}{l}\text { polymeric } \\
\text { film } \\
1{ }^{\circ} \mathrm{C} \\
\text { (7 days) }\end{array}$ \\
\hline & $80 \%$ & \multicolumn{2}{|c|}{$56 \%$} & $6 \%$ & $40 \%$ \\
\hline & \multicolumn{5}{|c|}{ Cooking Conditions } \\
\hline & hot water washing & $\begin{array}{l}\text { high } \\
\text { pressure } \\
\text { boiling }\end{array}$ & $\begin{array}{l}\text { conventional pressure } \\
\text { boiling }\end{array}$ & steaming & microwave \\
\hline $\begin{array}{c}\mathrm{GL}^{* * *} \\
\text { decrease }\end{array}$ & up to $40 \%$ & $33 \%$ & $55 \%$ & $20 \%$ & $74 \%$ \\
\hline
\end{tabular}

Further, it was observed that environmental, cultivar, and genetic factors as well as industrial processing, storage, and domestic cooking contribute to a change in GL concentrations [25,90]. Additionally, GL content can be affected by the preparation of brassica vegetables before cooking. It was shown that vegetable washing methods after cutting, such as hot/cold water use or different soaking times in water, may enhance the loss of glucosinolates because of their water-solubility properties [91].

Furthermore, when brassica vegetables are ingested, GLs continue to be hydrolyzed by active plant myrosinase in the upper gastrointestinal tract [93] and successively in the colon by the bacterial microflora, which produce the myrosinase enzyme [94-96], affecting their bioavailability.

It has been demonstrated that the inter-individual variation in GL hydrolysis is mainly dependent on differences in bacterial microflora between individuals. Bacteria such as Lactobacillus plantarum KW30 and Lactococcus lactis ssp. lactis KF147 were found to be able to transform 30-33\% of glucoraphanin and/or glucoerucin into sulforaphane nitrile, erucin nitrile, and some unknown metabolites. Furthermore, Lactobacillus agilis R16, another lactic acid bacterial strain, was reported to be capable of hydrolyzing sinigrin (SNG) into allyl isothiocyanate (AITC) [96]. More microorganisms were also reported to exhibit myrosinase activity, such as Bacillus cereus and Aspergillus niger [97-101]. Furthermore, the decrease in GL hydrolysis in the gut may depend on bowel microflora reduction due to mechanical cleansing and/or antibiotic treatment.

However, although the colonic microflora is capable of transforming GLs into their active metabolites, the role of plant-derived myrosinase was shown as critical for maximal ITC production in the gut. This finding is supported by a study where a lower bioavailability and delayed appearance of ITC metabolites were observed in the biological fluids (plasma and urine) of individuals consuming a broccoli supplement lacking myrosinase versus those consuming fresh broccoli sprouts. These differences may partially be explained by the fact that plant- and aphid-derived, but not 
bacterial-derived, myrosinases belong to the glycoside hydrolase (GH) family GH1 and exhibit differences in their activity $[102,103]$.

In humans, the absorption of isothiocyanates occurs in the intestinal epithelial cells, followed by release into the systemic circulation and successive metabolism in the liver through the mercapturic acid (MA) pathway. In particular, ITCs form conjugates with glutathione and are successively subjected to enzymatic modification and are released in urine as $\mathrm{N}$-acetylcysteine conjugates or MA products $[104,105]$. The measurement of the latter (MA) in urine has been used to provide the overall ITC uptake after Brassica consumption [106-111].

After brassica ingestion, GL hydrolysis and ITC absorption are influenced by the residual glucosinolate concentrations, as well as the plant myrosinase activity and the composition of the gut microflora and genotypic variation $[93,108,112]$. Additionally, the fate of glucosinolates is affected by the time they are in the gastrointestinal tract, their delivery to the small intestine for hydrolysis and/or absorption, and the extent of colonic fermentation [113]. Moreover, individuals may show different GL metabolism as a result of polymorphisms in genes coding for glutathione-S-transferases (GST). It plays a key role in isothiocyanate conjugation with glutathione to different extents, which is critical before the excretion of isothiocyanates as MA molecules [112].

Therefore, the quantities of available active ITCs after the consumption of cooked cruciferous vegetables may differ depending on inter-individual differences in the gut microflora due to genetics, environment, or diseases. In particular, differences in the intestinal flora of patients should be evaluated when pre-clinical trials involving cruciferous vegetables are designed. Different types of broccoli supplements containing broccoli and microflora-derived myrosinase may be explored for the development of novel anti-cancer therapeutic strategies based on brassica-derived agents.

\section{Conclusions}

Several studies have shown a correlation between nutrition and cancer risk, although homogeneous data are missing. It was reported that frequent consumption of fruits and vegetables is correlated with better clinical outcomes in ovarian cancer patients after surgery [114], as well as with a reduction in the risk for bladder cancer when combined with milk/yogurt consumption. This is in contrast with the high risk associated with meat consumption, which is related more to the cooking preparation than to the kind of meat [115].

Interestingly, many benefits such as reduced risk of cardiovascular disease, diabetes, and different types of cancer, like prostate, gastric, colorectal, liver, and breast, have been recorded in populations that follow the Mediterranean diet, which is rich in vegetables, legumes, fruits, whole grains, and fish and olive oil as fat sources, and involves moderate consumption of eggs and meat [116].

Further, research demonstrated that the consumption of broccoli, cauliflower, cabbage, or rocket salad is associated with a lower risk of developing cancer. We reviewed the chemopreventive and anti-cancer properties of Brassicaceae dietary agents and their pharmacological potential as remedies in cancer therapy. In particular, we focused on glucosinolates as a good source of active metabolites, which could be used for the development of efficacious therapeutic strategies with reduced side effects.

Since 2007, epidemiological studies on the association between the consumption of cruciferous vegetables and cancer risk have been carried out [117]. A lower risk of colorectal, cervical, and lung cancers was found to be associated with a high intake of cruciferous vegetables [117]. Recently, the consumption of cruciferous vegetables has been associated with a low breast cancer risk in Chinese women [118]. Although the data show an evident correlation between cruciferous vegetable consumption and low cancer risk, this study did not take into account the entire diet followed by Chinese women, which is different from those consumed by women in other countries, as are the cooking procedures for vegetables.

Although very promising, the variation in glucosinolate concentration and myrosinase activity within and between Brassica species as well as the microbiota influence are sources of variability in active metabolites present in these foods and can partly explain the weak relationship between Brassica 
consumption and preventive effects against cancer in men, which were observed in cohort studies. Interestingly, a recent study on the bioavailability of glucoraphanin and SFN from broccoli with different genotypes demonstrated that a broccoli variety with a high glucoraphanin content (Brassica villosa with the Myb28 V/V genotype), when delivered as soup to humans, resulted in enhanced SFN plasma levels, compared to the same variety with a low glucoraphanin content, suggesting its health benefits [118].

More studies including heterogeneous sets of populations and focused on the follow up of cancer patients during their treatment in association with increased use of cruciferous vegetables in the diet, as well as studies on the bioavailability properties of active brassica compounds, are necessary.

Author Contributions: All authors contributed to the writing of this manuscript. All authors have read and agreed to the published version of the manuscript.

Funding: This work was supported by Regione Campania, through a PO FESR 2014-2020 “SATIN" grant to E.C.

Conflicts of Interest: The authors declare no conflicts of interest.

\section{References}

1. Lee, C.S.; Baek, J.; Han, S.Y. The Role of Kinase Modulators in Cellular Senescence for Use in Cancer Treatment. Molecules 2017, 22, E1411. [CrossRef] [PubMed]

2. Fridlender, M.; Kapulnik, Y.; Koltai, H. Plant derived substances with anti-cancer activity: From folklore to practice. Front. Plant Sci. 2015, 6, 799. [CrossRef] [PubMed]

3. Morrissey, K.M.; Yuraszeck, T.M.; Li, C.C.; Zhang, Y.; Kasichayanula, S. Immunotherapy and Novel Combinations in Oncology: Current Landscape, Challenges, and Opportunities. Clin. Transl. Sci. 2016, 9 , 89-104. [CrossRef] [PubMed]

4. Gordaliza, M. Natural products as leads to anticancer drugs. Clin. Transl. Oncol. 2007, 9, 767-776. [CrossRef] [PubMed]

5. Sturm, C.; Wagner, A.E. Brassica-derived plant bioactives as modulators of chemopreventive and inflammatory signaling pathways. Int. J. Mol. Sci. 2017, 18, E1890. [CrossRef] [PubMed]

6. Johson, I.T. Cruciferous vegetables and risk of cancer of the gastrointestinal tract. Mol. Nutr. Food Res. 2018, 62, e1701000. [CrossRef]

7. Al-Shehbaz, I.A. A generic and tribal synopsis of the Brassicaceae (Cruciferae). Taxon 2012, 61, 931-954. [CrossRef]

8. Hedge, I.C. A systematic and geographical survey of the Old World Cruciferae. In The Biology and Chemistry of the Cruciferae; MacLeod, A.J., Jones, B.M.G., Eds.; Academic Press: London, UK; New York, NY, USA; San Francisco, CA, USA, 1976; pp. 1-45.

9. Appel, O.; Al-Shehbaz, I.A. Cruciferae. In The Families and Genera of Vascular Plants; Kubitzki, K., Bayer, C., Eds.; Springer: Berlin/Heidelberg, Germany, 2003; pp. 75-174.

10. Franzke, A.; German, D.; Al-Shehbaz, I.A.; Mummenhoff, K. Arabidopsis family ties: Molecular phylogeny and age estimates in the Brassicaceae. Taxon 2008, 58, 425-437. [CrossRef]

11. Karl, R.; Koch, M.A. A world-wide perspective on crucifer speciation and evolution: Phylogeny, biogeography and trait evolution in tribe Arabideae. Ann. Bot. 2013, 112, 983-1001. [CrossRef]

12. Özüdoğru, B.; Akaydın, G.; Erik, S.; Al-Shehbaz, I.A.; Mummenhoff, K. Phylogeny, diversification and biogeographic implications of the eastern Mediterranean endemic genus Ricotia (Brassicaceae). Taxon 2015, 64, 727-740. [CrossRef]

13. Hall, J.C.; Sytsma, K.J.; Iltis, H.H. Phylogeny of Capparaceae and Brassicaceae based on chloroplast sequence data. Am. J. Bot. 2002, 89, 1826-1842. [CrossRef] [PubMed]

14. Hall, J.C.; Iltis, H.H.; Sytsma, K.J. Molecular phylogenetics of core Brassicales, placement of orphan genera Emblingia, Forchhammeria, Tirania, and character evolution. Syst. Bot. 2004, 29, 654-669. [CrossRef]

15. Huang, C.H.; Sun, R.; Hu, Y.; Zeng, L.; Zhang, N.; Cai, L.; Zhang, Q.; Koch, M.A.; Al-Shehbaz, I.; Edger, P.P.; et al. Resolution of Brassicaceae phylogeny using nuclear genes uncovers nested radiations and supports convergent morphological evolution. Mol. Biol. Evol. 2016, 33, 394-412. [CrossRef] [PubMed]

16. Fahey, J.W.; Zalcmann, A.T.; Talalay, P. The chemical diversity and distribution of glucosinolates and isothiocyanates among plants. Phytochemistry 2001, 56, 5-51. [CrossRef] 
17. Fenwick, G.R.; Heaney, R.K.; Mullin, W.J. Glucosinolates and their breakdown products in food and food plants. Crit. Rev. Food Sci. Nutr. 1983, 18, 123-201. [CrossRef] [PubMed]

18. Higdon, J.V.; Delage, B.; Williams, D.E.; Dashwood, R.H. Cruciferous vegetables and human cancer risk: Epidemiologic evidence and mechanistic basis. Pharmacol. Res. 2007, 55, 224-236. [CrossRef]

19. Holst, B.; Williamson, G. A critical review of the bioavailability of glucosinolates and related compounds. Nat. Prod. Rep. 2004, 21, 425-447. [CrossRef]

20. Agerbirk, N.; Olsen, C.E. Glucosinolate structures in evolution. Phytochemistry 2012, 77, 16-45. [CrossRef]

21. Blaževic, I.; Montaut, S.; Burcul, F.; Rollin, P. Glucosinolates: Novel sources and biological potential. In Glucosinolates; Mérillon, J.M., Ramawat, G.K., Eds.; Springer International Publishing: Cham, Switzerland, 2016; pp. 3-60.

22. Daxenbichler, M.E.; Spencer, G.F.; Carlson, D.G.; Rose, G.B.; Brinker, A.M.; Powell, R.G. Glucosinolate composition of seeds from 297 species of wild plants. Phytochemistry 1991, 30, 2623-2638. [CrossRef]

23. Dinkova-Kostova, A.T.; Kostov, R.V. Glucosinolates and isothiocyanates in health and disease. Trends Mol. Med. 2012, 18, 337-347. [CrossRef]

24. Kelly, P.; Bones, A.; Rossiter, J. Sub-cellular immune-localization of the glucosinolate sinigrin in seedlings of Brassica juncea. Planta 1998, 206, 370-377. [CrossRef] [PubMed]

25. Bones, A.M.; Rossiter, J.T. The myrosinase-glucosinolate system, its organisation and biochemistry. Physiol. Plant. 1996, 97, 194-208. [CrossRef]

26. Hanschen, F.S.; Herz, C.; Schlotz, N.; Kupke, F.; Bartolomé Rodríguez, M.M.; Schreiner, M.; Rohn, S.; Lamy, E. The Brassica epithionitrile 1-cyano-2,3-epithiopropane triggers cell death in human liver cancer cells in vitro. Mol. Nutr. Food Res. 2015, 59, 2178-2189. [CrossRef] [PubMed]

27. Klopsch, R.; Witzel, K.; Börner, A.; Schreiner, M.; Hanschen, F.S. Metabolic profiling of glucosinolates and their hydrolysis products in a germplasm collection of Brassica rapa turnips. Food Res. Int. 2017, 100, $392-403$. [CrossRef]

28. Rungapamestry, V.; Duncan, A.J.; Fuller, Z.; Ratcliffe, B. Changes in glucosinolate concentrations, myrosinase activity, and production of metabolites of glucosinolates in cabbage (Brassica oleracea Var. capitata) cooked for different durations. J. Agric. Food Chem. 2006, 54, 7628-7634. [CrossRef]

29. Burow, M.; Losansky, A.; Müller, R.; Plock, A.; Kliebenstein, D.J.; Wittstock, U. The genetic basis of constitutive and herbivore-induced ESP-independent nitrile formation in Arabidopsis. Plant Physiol. 2009, 561-574. [CrossRef]

30. Wittstock, U.; Burow, M. Glucosinolate breakdown in Arabidopsis: Mechanism, regulation and biological significance. Arab. Book 2010, 8, e0134. [CrossRef]

31. Matusheski, N.V.; Swarup, R.; Juvik, J.A.; Mithen, R.; Bennett, M.; Jeffery, E.H. Epithiospecifier protein from broccoli (Brassica oleracea L. ssp. italica) inhibits formation of the anticancer agent sulforaphane. J. Agric. Food Chem. 2006, 54, 2069-2076. [CrossRef]

32. Halkier, B.A.; Gershenzon, J. Biology and biochemistry of glucosinolates. Annu. Rev. Plant Biol. 2006, 57, 303-333. [CrossRef]

33. Winde, I.; Wittstock, U. Insect herbivore counter-adaptations to the plant glucosinolate-myrosinase system. Phytochemistry 2011, 72, 1566-1575. [CrossRef]

34. Cole, R.A. Isothiocyanates, nitriles and thiocyanates as products of autolysis of glucosinolates in Cruciferae. Phytochemistry 1976, 15, 759-762. [CrossRef]

35. Kadir, N.H.; David, R.; Rossiter, J.T.; Gooderham, N.J. The selective cytotoxicity of the alkenyl glucosinolate hydrolysis products and their presence in Brassica vegetables. Toxicology 2015, 334, 59-71. [CrossRef] [PubMed]

36. Verkerk, R.; Schreiner, M.; Krumbein, A.; Ciska, E.; Holst, B.; Rowland, I.; De Schrijver, R.; Hansen, M.; Gerhäuser, C.; Mithen, R.; et al. Glucosinolates in Brassica vegetables: The influence of the food supply chain on intake, bioavailability and human health. Mol. Nutr. Food Res. 2009, 53 (Suppl. 2), S219. [CrossRef] [PubMed]

37. Renaud, E.N.; Lammerts van Bueren, E.T.; Myers, J.R.; Paulo, M.J.; van Eeuwijk, F.A.; Zhu, N.; Juvik, J.A. Variation in broccoli cultivar phytochemical content under organic and conventional management systems: Implications in breeding for nutrition. PLoS ONE 2014, 9, e95683. [CrossRef] [PubMed] 
38. Mumm, R.; Burow, M.; Bukovinszkine'Kiss, G.; Kazantzidou, E.; Wittstock, U.; Dicke, M.; Gershenzon, J. Formation of simple nitriles upon glucosinolate hydrolysis affects direct and indirect defense against the specialist herbivore. Pieris rapae. J. Chem. Ecol. 2008, 34, 1311-1321. [CrossRef]

39. Textor, S.; Gershenzon, J. Herbivore induction of the glucosinolate-myrosinase defense system: Major trends, biochemical bases and ecological significance. Phytochem. Rev. 2009, 8, 149-170. [CrossRef]

40. Brown, P.D.; Tokuhisa, J.G.; Reichelt, M.; Gershenzon, J. Variation of glucosinolate accumulation among different organs and developmental stages of Arabidopsis thaliana. Phytochemistry 2003, 62, 471-481. [CrossRef]

41. Bellostas, N.; Sørensen, A.D.; Sørensen, J.C.; Sørensen, H. Fe ${ }^{2+}$-catalyzed formation of nitriles and thionamides from intact glucosinolates. J. Nat. Prod. 2008, 71, 76-80. [CrossRef]

42. Pérez-Balibrea, S.; Moreno, D.A.; García-Viguera, C. Glucosinolates in broccoli sprouts (Brassica oleracea var. italica) as conditioned by sulphate supply during germination. J. Food Sci. 2010, 75, C673-C677. [CrossRef]

43. Hecht, S.S. Inhibition of carcinogenesis by isothiocyanates. Drug Metab. Rev. 2000, 32, 395-411. [CrossRef]

44. Gupta, P.; Kim, B.; Kim, S.H.; Srivastava, S.K. Molecular targets of isothiocyanates in cancer: Recent advances. Mol. Nutr. Food Res. 2014, 58, 1685-1707. [CrossRef] [PubMed]

45. Hanlon, N.; Coldham, N.; Gielbert, A.; Kuhnert, N.; Sauer, M.J.; King, L.J.; Ioannides, C. Absolute bioavailability and dose-dependent pharmacokinetic behaviour of dietary doses of the chemopreventive isothiocyanate sulforaphane in rat. Br. J. Nutr. 2008, 99, 559-564. [CrossRef] [PubMed]

46. Zhang, Y. Cancer-preventive isothiocyanates: Measurement of human exposure and mechanism of action. Mutat. Res. 2004, 555, 173-190. [CrossRef] [PubMed]

47. Traka, M.H.; Melchini, A.; Coode-Bate, J.; Al Kadhi, O.; Saha, S.; Defernez, M.; Troncoso-Rey, P.; Kibblewhite, H.; O'Neill, C.M.; Bernuzzi, F.; et al. Transcriptional changes in prostate of men on active surveillance after a 12-mo glucoraphanin-rich broccoli intervention-results from the Effect of Sulforaphane on prostate CAncer PrEvention (ESCAPE) randomized controlled trial. Am. J. Clin. Nutr. 2019, 109, 1133-1144. [CrossRef]

48. Cornblatt, B.S.; Ye, L.; Dinkova-Kostova, A.T.; Erb, M.; Fahey, J.W.; Singh, N.K.; Chen, M.S.; Stierer, T.; Garrett-Mayer, E.; Argani, P.; et al. Preclinical and clinical evaluation of sulforaphane for chemoprevention in the breast. Carcinogenesis 2007, 28, 1485-1490. [CrossRef]

49. Tortorella, S.M.; Royce, S.G.; Licciardi, P.V.; Karagiannis, T.C. Dietary Sulforaphane in Cancer Chemoprevention: The Role of Epigenetic Regulation and HDAC Inhibition. Antioxid Redox Signal. 2015, 22, 1382-1424. [CrossRef]

50. Burnett, J.P.; Lim, G.; Li, Y.; Shah, R.B.; Lim, R.; Paholak, H.J.; McDermott, S.P.; Sun, L.; Tsume, Y.; Bai, S.; et al. Sulforaphane enhances the anticancer activity of taxanes against triple negative breast cancer by killing cancer stem cells. Cancer Lett. 2017, 394, 52-64. [CrossRef]

51. Cao, S.; Wang, L.; Zhang, Z.; Chen, F.; Wu, Q.; Li, L. Sulforaphane-induced metabolomic responses with epigenetic changes in estrogen receptor positive breast cancer cells. FEBS Open Bio 2018, 8, 2022-2034. [CrossRef]

52. Aumeeruddy, M.Z.; Mahomoodally, M.F. Combating Breast Cancer Using Combination Therapy with 3 Phytochemicals: Piperine, Sulforaphane, and Thymoquinone. Cancer 2019, 125, 1600-1611. [CrossRef]

53. Castro, N.P.; Rangel, M.C.; Merchant, A.S.; MacKinnon, G.; Cuttitta, F.; Salomon, D.S.; Kim, Y.S. Sulforaphane Suppresses the Growth of Triple-negative Breast Cancer Stem-like Cells In vitro and In vivo. Cancer Prev Res (Phila). 2019, 12, 147-158. [CrossRef]

54. Cheng, A.C.; Shen, C.J.; Hung, C.M.; Hsu, Y.C. Sulforaphane Decrease of SERTAD1 Expression Triggers G1/S Arrest in Breast Cancer Cells. J. Med. Food 2019, 22, 444-450. [CrossRef] [PubMed]

55. Chaudhuri, D.; Orsulic, S.; Ashok, B.T. Antiproliferative activity of sulforaphane in Akt-overexpressing ovarian cancer cells. Mol. Cancer Ther. 2007, 6, 334-345. [CrossRef] [PubMed]

56. Chuang, L.T.; Nagarsheth, N.; Hayes, M.P.; Zakashansky, K.; Gretz, H., III; Nezhat, F.R.; Wu, X.; Fishman, D.; Chiao, J.C. Sulforaphane Induces Cell Cycle Arrest, Migration, Invasion, and Apoptosis in Epithelial Ovarian Cancer Cells. Am. J. Cancer Rev. 2013, 1, 9-24.

57. Pastorek, M.; Simko, V.; Takacova, M.; Barathova, M.; Bartosova, M.; Hunakova, L.; Sedlakova, O.; Hudecova, S.; Krizanova, O.; Dequiedt, F.; et al. Sulforaphane reduces molecular response to hypoxia in ovarian tumor cells independently of their resistance to chemotherapy. Int. J. Oncol. 2015, 47, 51-60. [CrossRef] [PubMed] 
58. Arcidiacono, P.; Kuligina, E.; Crisanti, A.; Ragonese, F.; Rende, M.; Spaccapelo, R.; Stabile, A.; Bottoni, U.; Pistilli, A.; Calvieri, S. Antitumor activity and expression profiles of genes induced by sulforaphane in human melanoma cells. Eur. J. Nutr. 2018, 57, 2547-2569. [CrossRef] [PubMed]

59. Citi, V.; Piragine, E.; Pagnotta, E.; Ugolini, L.; Di Cesare Mannelli, L.; Testai, L.; Ghelardini, C.; Lazzeri, L.; Calderone, V.; Martelli, A. Anticancer properties of erucin, an H2S. releasing isothiocyanate, on human pancreatic adenocarcinoma cells (AsPC-1). Phytother. Res. 2019, 33, 845-855. [CrossRef] [PubMed]

60. Ma, T.T.; Zhou, L.Q.; Xia, J.H.; Shen, Y.; Yan, Y.; Zhu, R.H. LncRNA PCAT-1 regulates the proliferation, metastasis and invasion of cervical cancer cells. Eur. Rev. Med. Pharmacol. Sci. 2018, 22, 1907-1913.

61. Lu, S.; Gao, Y.; Huang, X.; Wang, X. Cantharidin exerts anti-hepatocellular carcinoma by miR-214 modulating macrophage polarization. Int. J. Biol. Sci. 2014, 10, 415-425. [CrossRef]

62. De Cicco, P.; Panza, E.; Armogida, C.; Ercolano, G.; Taglialatela-Scafati, O.; Shokoohinia, Y.; Camerlingo, R.; Pirozzi, G.; Calderone, V.; Cirino, G.; et al. The Hydrogen Sulfide Releasing Molecule Acetyl Deacylasadisulfide Inhibits Metastatic Melanoma. Front. Pharmacol. 2017, 8, 65. [CrossRef]

63. Kaczyńska, A.; Herman-Antosiewicz, A. Combination of lapatinib with isothiocyanates overcomes drug resistance and inhibits migration of HER2 positive breast cancer cells. Breast Cancer 2017, 24, 271-280. [CrossRef]

64. Bonnesen, C.; Eggleston, I.M.; Hayes, J.D. Dietary indoles and isothiocyanates that are generated from cruciferous vegetables can both stimulate apoptosis and confer protection against DNA damage in human colon cell lines. Cancer Res. 2001, 61, 6120-6130. [PubMed]

65. Frydoonfar, H.R.; McGrath, D.R.; Spigelman, A.D. Inhibition of proliferation of a colon cancer cell line by indole-3-carbinol. Colorectal Dis. 2002, 4, 205-207. [CrossRef] [PubMed]

66. Zheng, Q.; Hirose, Y.; Yoshimi, N.; Murakami, A.; Koshimizu, K.; Ohigashi, H.; Sakata, K.; Matsumoto, Y.; Sayama, Y.; Mori, H. Further investigation of the modifying effect of various chemopreventive agents on apoptosis and cell proliferation in human colon cancer cells. J. Cancer Res. Clin. 2020, 128, 539-546. [CrossRef] [PubMed]

67. Hudson, E.A.; Howells, L.M.; Gallacher-Horley, B.; Fox, L.H.; Gescher, A.; Manson, M.M. Growth-inhibitory effects of the chemopreventive agent indole-3-carbinol are increased in combination with the polyamine putrescine in the SW480 colon tumour cell line. BMC Cancer 2003, 3, 2. [CrossRef]

68. Wang, X.; He, H.; Lu, Y.; Ren, W.; Teng, K.Y.; Chiang, C.L.; Yang, Z.; Yu, B.; Hsu, S.; Jacob, S.T.; et al. Indole-3-carbinol inhibits tumorigenicity of hepatocellular carcinoma cells via suppression of microRNA-21 and upregulation of phosphatase and tensin homolog. Biochim. Biophys. Acta 2015, 1853, 244-253. [CrossRef]

69. Danielsen, S.A.; Eide, P.W.; Nesbakken, A.; Guren, T.; Leithe, E.; Lothe, R.A. Portrait of the PI3K/AKT pathway in colorectal cancer. Biochim. Biophys. Acta 2015, 1855, 104-121. [CrossRef]

70. Caruso, J.A.; Campana, R.; Wei, C.; Su, C.H.; Hanks, A.M.; Bornmann, W.G.; Keyomarsi, K. Indole-3-carbinol and its $\mathrm{N}$-alkoxy derivatives preferentially target ER $\alpha$-positive breast cancer cells. Cell Cycle 2014, 13, 2587-2599. [CrossRef]

71. Hargraves, K.G.; He, L.; Firestone, G.L. Phytochemical regulation of the tumor suppressive microRNA, miR-34a, by p53-dependent and independent responses in human breast cancer cells. Mol. Carcinog. 2016, 55, 486-498. [CrossRef]

72. Wu, Y.; Li, R.W.; Huang, H.; Fletcher, A.; Yu, L.; Pham, Q.; Yu, L.; He, Q.; Wang, T.T.Y. Inhibition of Tumor Growth by Dietary Indole-3-Carbinol in a Prostate Cancer Xenograft Model May Be Associated with Disrupted Gut Microbial Interactions. Nutrients 2019, 11, 467. [CrossRef]

73. Vermeulen, M.; Klopping-Ketelaars, I.W.; van den Berg, R.; Vaes, W.H. Bioavailability and kinetics of sulforaphane in humans after consumption of cooked versus raw broccoli. J. Agric. Food Chem. 2008, 56, 10505-10509. [CrossRef]

74. Bao, Y.; Wang, W.; Zhou, Z.; Sun, C. Benefits and risks of the hormetic effects of dietary isothiocyanates on cancer prevention. PLoS ONE 2014, 9, e114764. [CrossRef] [PubMed]

75. Feitelson, M.A.; Arzumanyan, A.; Kulathinal, R.J.; Blain, S.W.; Holcombe, R.F.; Mahajna, J.; Marino, M.; Martinez-Chantar, M.L.; Nawroth, R.; Sanchez-Garcia, I.; et al. Sustained proliferation in cancer: Mechanisms and novel therapeutic targets. Semin. Cancer Biol. 2015, 35, S25-S54. [CrossRef] [PubMed]

76. Singh, A.K.; Sharma, N.; Ghosh, M.; Park, Y.H.; Jeong, D.K. Emerging importance of dietary phytochemicals in fight against cancer: Role in targeting cancer stem cells. Crit. Rev. Food Sci. Nutr. 2017, 57, 3449-3463. [CrossRef] [PubMed] 
77. Wang, F.; Wang, W.; Li, J.; Zhang, J.; Wang, X.; Wang, M. Sulforaphane reverses gefitinib tolerance in human lung cancer cells via modulation of sonic hedgehog signaling. Oncol. Lett. 2018, 15, 109-114. [CrossRef]

78. Rodova, M.; Fu, J.; Watkins, D.N.; Srivastava, R.K.; Shankar, S. Sonic hedgehog signaling inhibition provides opportunities for targeted therapy by sulforaphane in regulating pancreatic cancer stem cell self-renewal. PLOS ONE 2012, 7, e46083. [CrossRef]

79. Ge, M.; Zhang, L.; Cao, L.; Xie, C.; Li, X.; Li, Y.; Meng, Y.; Chen, Y.; Wang, X.; Chen, J.; et al. Sulforaphane inhibits gastric cancer stem cells via suppressing sonic hedgehog pathway. Int. J. Food Sci. Nutr. 2019, 70, 570-578. [CrossRef]

80. Melchini, A.; Traka, M.H. Biological profile of erucin: A new promising anticancer agent from cruciferous vegetables. Toxins 2010, 2, 593-612. [CrossRef]

81. Citi, V.; Martelli, A.; Testai, L.; Marino, A.; Breschi, M.C.; Calderone, V. Hydrogen sulfide releasing capacity of natural isothiocyanates: Is it a reliable explanation for the multiple biological effects of Brassicaceae? Planta Med. 2014, 80, 610-613. [CrossRef]

82. Lucarini, E.; Micheli, L.; Trallori, E.; Citi, V.; Martelli, A.; Testai, L.; De Nicola, G.R.; Iori, R.; Calderone, V.; Ghelardini, C.; et al. Effect of glucoraphanin and sulforaphane against chemotherapy-induced neuropathic pain: Kv7 potassium channels modulation by $\mathrm{H}_{2} \mathrm{~S}$ release in vivo. Phytother. Res. 2018, 32, 2226-2234. [CrossRef]

83. Hellmich, M.R.; Coletta, C.; Chao, C.; Szabo, C. The therapeutic potential of cystathionine $\beta$-synthetase/hydrogen sulfide inhibition in cancer. Antioxid. Redox Signal. 2015, 22, 424-448. [CrossRef]

84. Calderone, V.; Martelli, A.; Testai, L.; Citi, V.; Breschi, M.C. Using hydrogen sulfide to design and develop drugs. Expert Opin. Drug Discov. 2016, 11, 163-175. [CrossRef] [PubMed]

85. Ahmad, A.; Sakr, W.A.; Rahman, K.M. Anticancer properties of indole compounds. Curr. Drug Targets 2010, 11, 652-666. [CrossRef] [PubMed]

86. Dekker, M.; Verkerk, R.; Jongen, W.M.F. Predictive modelling of health aspects in the food production chain: A case study on glucosinolates in cabbage. Trends Food Sci. Technol. 2000, 11, 174-181. [CrossRef]

87. Verkerk, R.; Dekker, M. Glucosinolates and myrosinase activity in red cabbage (Brassica oleracea L. var. capitataf. rubra DC.) after various microwave treatments. J. Agric. Food Chem. 2004, 52, 7318-7323. [CrossRef]

88. Goodrich, R.M.; Anderson, J.L.; Stoewsand, G.S. Glucosinolate changes in blanched broccoli and Brussels-sprouts. J. Food Process. Preserv. 1989, 13, 275-280. [CrossRef]

89. Rodrigues, A.S.; Rosa, E.A.S. Effect of post-harvest treatments on the level of glucosinolates in broccoli. J. Sci. Food Agric. 1999, 79, 1028-1032. [CrossRef]

90. Vallejo, F.; Tomas-Barberan, F.A.; Garcia-Viguera, C. Health promoting compounds in broccoli as influenced by refrigerated transport and retail sale period. J. Agric. Food Chem. 2003, 51, 3029-3034. [CrossRef]

91. Vallejo, F.; Tomas-Barberan, F.A.; Garcı-Viguera, C. Glucosinolates and vitamin C content in edible parts of broccoli florets after domestic cooking. Eur. Food Res. Technol. 2002, 215, 310-316.

92. Lambrix, V.; Reichelt, M.; Mitchell-Olds, T.; Kliebenstein, D.J.; Gershenzon, J. The Arabidopsis epithiospecifier protein promotes the hydrolysis of glucosinolates to nitriles and influences Trichoplusiani herbivory. Plant Cell 2001, 13, 2793-2807. [CrossRef]

93. Rouzaud, G.; Rabot, S.; Ratcliffe, B.; Duncan, A.J. Influence of plant and bacterial myrosinase activity on the metabolic fate of glucosinolates in gnotobiotic rats. Br. J. Nutr. 2003, 90, 395-404. [CrossRef]

94. Rabot, S.; Nugon-Baudon, L.; Raibaud, P.; Szylit, O. Rapeseed meal toxicity in gnotobiotic rats: Influence of a whole human fecal flora or single human strains of Escherichia coli and Bacteroides vulgatus. Br. J. Nutr. 1993, 70, 323-331. [CrossRef] [PubMed]

95. Michaelsen, S.; Otte, J.; Simonsen, L.O.; Sorensen, H. Absorption and degradation of individual intact glucosinolates in the digestive tract of rodents. Acta Agric. Scand. 1994, 44, 25-37. [CrossRef]

96. Krul, C.; Humblot, C.; Philippe, C.; Vermeulen, M.; van Nuenen, M.; Havenaar, R.; Rabot, S. Metabolism of sinigrin (2-propenyl glucosinolate) by the human colonic microflora in a dynamic in vitro large-intestinal model. Carcinogenesis 2002, 23, 1009-1016. [CrossRef] [PubMed]

97. Palop, M.L.; Smiths, J.P.; Tenbrink, B. Degradation of sinigrin by Lactobacillus agilis strain R16. Int. J. Food Microbiol. 1995, 26, 219-229. [CrossRef]

98. Li, F.; Hullar, M.A.J.; Beresford, S.A.A.; Lampe, J.W. Variation of glucoraphanin metabolism in vivo and ex vivo by human gut bacteria. Br. J. Nutr. 2011, 106, 408-416. [CrossRef] 
99. Elfoul, L.; Rabot, S.; Khelifa, N.; Quinsac, A.; Duguay, A.; Rimbault, A. Formation of allyl isothiocyanate fromsinigrin in the digestive tract of rats mono-associated with a human colonic strain of Bacteroides thetaiotaomicron. FEMS Microbiol. Lett. 2001, 197, 99-103. [CrossRef]

100. Mullaney, J.A.; Kelly, W.J.; McGhie, T.K.; Ansell, J.; Heyes, J.A. Lactic acid bacteria convert glucosinolates to nitriles efficiently yet differently from Enterobacteriaceae. J. Agric. Food Chem. 2013, 61, 3039-3046. [CrossRef]

101. Ohtsuru, M.T.I.; Hata, T. The production and stability of intracellular myrosinase from Aspergillus niger. Agric. Biol. Chem. 1973, 37, 967-971. [CrossRef]

102. Mahn, A.; Angulo, A.; Cabanas, F. Purification and characterization of broccoli (Brassica oleracea var. italica) myrosinase (beta-thioglucosidase glucohydrolase). J. Agric. Food Chem. 2014, 62, 11666-11671. [CrossRef]

103. Jones, A.M.E.; Bridges, M.; Bones, A.M.; Cole, R.; Rossiter, J.T. Purification and characterisation of a non-plant myrosinase from the cabbage aphid Brevicoryne brassicae (L.). Insect. Biochem. Mol. 2001, 31, 1-5. [CrossRef]

104. Brusewitz, G.; Cameron, B.D.; Chasseaud, L.F.; Gorler, K.; Hawkins, D.R.; Koch, H.; Mennicke, W.H. The metabolism of benzyl isothiocyanate and its cysteine conjugate. Biochem. J. 1977, 162, 99-107. [CrossRef]

105. Mennicke, W.H.; Gorler, K.; Krumbiegel, G. Metabolism of some naturally occurring isothiocyanates in the rat. Xenobiotica 1983, 13, 203-207. [CrossRef]

106. Getahun, S.M.; Chung, F.L. Conversion of glucosinolates to isothiocyanates in humans after ingestion of cooked watercress. Cancer Epidemiol. Biomark. Prev. 1999, 8, 447-451.

107. Conaway, C.C.; Getahun, S.M.; Liebes, L.L.; Pusateri, D.J.; Topham, D.K.W.; Botero-Omary, M.; Chung, F.L. Disposition of glucosinolates and sulforaphane in humans after ingestion of steamed and fresh broccoli. Nutr. Cancer 2000, 38, 168-178. [CrossRef] [PubMed]

108. Shapiro, T.A.; Fahey, J.W.; Wade, K.L.; Stephenson, K.K.; Talalay, P. Chemoprotective glucosinolates and isothiocyanates of broccoli sprouts: Metabolism and excretion in humans. Cancer Epidemiol. Biomark. Prev. 2001, 10, 501-508.

109. Rouzaud, G.; Young, S.A.; Duncan, A.J. Hydrolysis of glucosinolates to isothiocyanates after ingestion of raw or microwaved cabbage by human volunteers. Cancer Epidemiol. Biomark. Prev. 2004, 13, 125-131. [CrossRef]

110. Mennicke, W.H.; Gorler, K.; Krumbiegel, G.; Lorenz, D.; Rittmann, N. Studies on the metabolism and excretion of benzyl isothiocyanate in man. Xenobiotica 1988, 18, 441-447. [CrossRef]

111. Chung, F.L.; Jiao, D.; Getahun, S.M.; Yu, M.C. A urinary biomarker for uptake of dietary isothiocyanates in humans. Cancer Epidemiol. Biomark. Prev. 1998, 7, 103-108.

112. Seow, A.; Vainio, H.; Yu, M.C. Effect of glutathione-Stransferase polymorphisms on the cancer preventive potential of isothiocyanates: An epidemiological perspective. Mutat. Res. 2005, 592, 58-67. [CrossRef]

113. Stahl, W.; van den Berg, H.; Arthur, J.; Bast, A.; Dainty, J.; Faulks, R.M.; Gartner, C.; Haenen, G.; Hollman, P.; Holst, B. Bioavailability and metabolism. Mol. Asp. Med. 2002, 23, 39-100. [CrossRef]

114. Rinninella, E.; Fagotti, A.; Cintoni, M.; Raoul, P.; Scaletta, G.; Quagliozzi, L.; Miggiano, G.A.D.; Scambia, G.; Gasbarrini, A.; Mele, M.C. Nutritional Interventions to Improve Clinical Outcomes in Ovarian Cancer: A Systematic Review of Randomized Controlled Trials. Nutrients 2019, 11, 1404. [CrossRef] [PubMed]

115. Di Maso, M.; Turati, F.; Bosetti, C.; Montella, M.; Libra, M.; Negri, E.; Ferraroni, M.; La Vecchia, C.; Serraino, D.; Polesel, J. Food consumption, meat cooking methods and diet diversity and the risk of bladder cancer. Cancer Epidemiol. 2019, 63, 101595. [CrossRef] [PubMed]

116. Hernaez, A.; Estruch, R. The Mediterranean Diet and Cancer: What Do Human and Molecular Studies Have to Say about It? Nutrients 2019, 11, 2155. [CrossRef] [PubMed]

117. Zhang, N.-Q.; Ho, S.C.; Mo, X.-F.; Lin, F.-Y.; Huang, W.-Q.; Luo, H.; Huang, J.; Zhang, C.-X. Glucosinolate and isothiocyanate intakes are inversely associated with breast cancer risk: A case-control study in China. Br. J. Nutr. 2018, 119, 957. [CrossRef] [PubMed]

118. Sivapalan, T.; Melchini, A.; Saha, S.; Needs, P.W.; Traka, M.H.; Tapp, H.; Dainty, J.R.; Mithen, R.F. Bioavailability of Glucoraphanin and Sulforaphane from High-Glucoraphanin Broccoli. Mol. Nutr. Food Res. 2018, 62, e1700911. [CrossRef] [PubMed]

(C) 2020 by the authors. Licensee MDPI, Basel, Switzerland. This article is an open access article distributed under the terms and conditions of the Creative Commons Attribution (CC BY) license (http://creativecommons.org/licenses/by/4.0/). 